RESEARCH ARTICLE

\title{
Estimation of above ground biomass of a Pinus caribaea Morelet stand in lower Hantana
}

\author{
I.M. Ambagahaduwa ${ }^{1}$, N. Prasad ${ }^{1}$, I.A.U.N. Gunatilleke ${ }^{2}$, G. Seneviratne ${ }^{3^{*}}$ and C.V.S. Gunatilleke ${ }^{2}$ \\ ${ }^{I}$ Post Graduate Institute of Science, University of Peradeniya, Peradeniya. \\ ${ }^{2}$ Department of Botany, Faculty of Science, University of Peradeniya, Peradeniya. \\ ${ }^{3}$ Institute of Fundamental Studies, Hantana Road, Kandy.
}

Revised: 04 April 2009; Accepted: 19 June 2009

\begin{abstract}
Above ground biomass production was estimated in a 25 year-old Pinus caribaea stand in the land belonging to the University of Peradeniya, in lower Hantana in the Central Province. Twenty four pine trees felled were used to collect data for developing allometric biomass equations and to estimate the above ground biomass. Empirical formulae were derived to estimate the above ground biomass separately for the cylindrical lower part and the conical upper part of the pine trees. Using these site-specific formulae derived from empirical data, the above ground biomass of the 25 year-old $P$. caribaea stand was found to be $194 \mathrm{t} / \mathrm{ha}$. A second estimation of $136 \mathrm{t} / \mathrm{ha}$ for the above ground biomass was obtained using standard formulae. Of the live standing crop, the stem represented $60 \%$, the branches $17 \%$, leaves $13 \%$, cones $3 \%$ and dead branches $7 \%$. This pine stand had 695 pine trees/ha, a mean diameter at breast height (dbh) of $20.1 \mathrm{~cm}$, a mean height of $20.7 \mathrm{~m}$ and mean basal area of $23.6 \mathrm{~m}^{2} / \mathrm{ha}$. The estimated above ground biomass showed that the $P$. caribaea plantation studied is a good sink for sequestered carbon. Since the study was based on actual measurements through destructive sampling, yielding more accurate estimates than from standard derivations, the derived empirical formulae in this study are recommended for estimation of the above ground biomass of comparable pine tree stands in the Hantana plantation and also other plantations in similar steeply undulating topography. Based on a metaanalysis of literature data on $P$. caribaea in the tropics, it was found that a $P$. caribaea plantation up to an age of 25 years attains maximum above ground biomass when it reached ca. 22 years.
\end{abstract}

Keywords: Above ground biomass, carbon sequestration, empirical formulae, Pinus caribaea, tree form.

\section{INTRODUCTION}

Geographically, Sri Lanka is a small continental island in South Asia. Yet, it supports the largest biodiversity per unit area in its natural forests ${ }^{1}$. However, this natural forest cover is decreasing due to agriculture, agricultural land settlements, encroachments by landless poor and illegal logging. Presently, the islands natural forest cover is only 1.58 million hectares, about $25 \%$ of its total land area $^{1}$. The rise in demand for fuel wood, timber and fibre and the steady decrease in its natural forest cover paved the way to the establishment of extensive plantations of several exotic species of Eucalyptus, Pinus and Tectona since the early part of the $20^{\text {th }}$ century. This trend continued with the introduction of Forest Policy $1970^{1}$. Out of the 26,771 ha of pine plantation 25,091 ha are of Pinus caribaea (Caribbean pine), which established easily on depleted soils. Between 1980-85, P. caribaea was planted by the Forest Department under a reforestation project of the Mahaweli river catchment ${ }^{2}$. Forests have traditionally been used for many products, including timber, fuel wood and fodder but its new role as a carbon sink has opened new opportunities in carbon trading, which require more accurate inventory of their biomass.

There are two main approaches for estimating the biomass density of woody formations based on existing forest inventory data. The first approach is based on the use of existing measured volume estimates (VOB per ha) converted to biomass density ( $t / h a)$ using a variety of "tools". The second approach directly estimates biomass density using biomass regression equations ${ }^{3}$. The present study develops empirical formulae to estimate stem biomass based on actual destructive sampling of felled trees which has been used in the estimation of above ground biomass in P. caribaea.

\footnotetext{
*Corresponding author (gaminis@ifs.ac.lk)
} 


\section{METHODS AND MATERIALS}

This study was carried out in the Lower Hantana range (500 - $700 \mathrm{~m} \mathrm{amsl}$ ) belonging to the University of Peradeniya in the Kandy district $\left(7^{\circ} 05^{\prime} \mathrm{N}, 80^{\circ} 30^{\prime} \mathrm{E}\right)$ of central Sri Lanka. Climatically Hantana is a tropical humid region with an annual rainfall ranging between 2000 and $2500 \mathrm{~mm}$ and a mean annual temperature of ca. $24{ }^{\circ} \mathrm{C}^{4}$. The land form of the general area of Hantana mountainous land system is hilly and steeply dissected with narrow strongly sloping valleys. The soils belong to the USDA Soil Taxonomy category of Typic Troporthents (Reddish Brown Latosolic soils) underlain by residual material derived from quartz-rich middle pre-cambrian metamorphic rocks of the Highland Series ${ }^{5}$.

The Hantana pine plantations were established in the 1980 s with a view to restore the degraded grasslands. These plantations had not been silviculturally managed since their establishment. Several rows of mature P. caribaea trees totaling 126 trees were removed in one pine stand to establish an enrichment trial with indigenous tree species which gave an opportunity to determine the biomass of a sample of the trees felled. The total tree
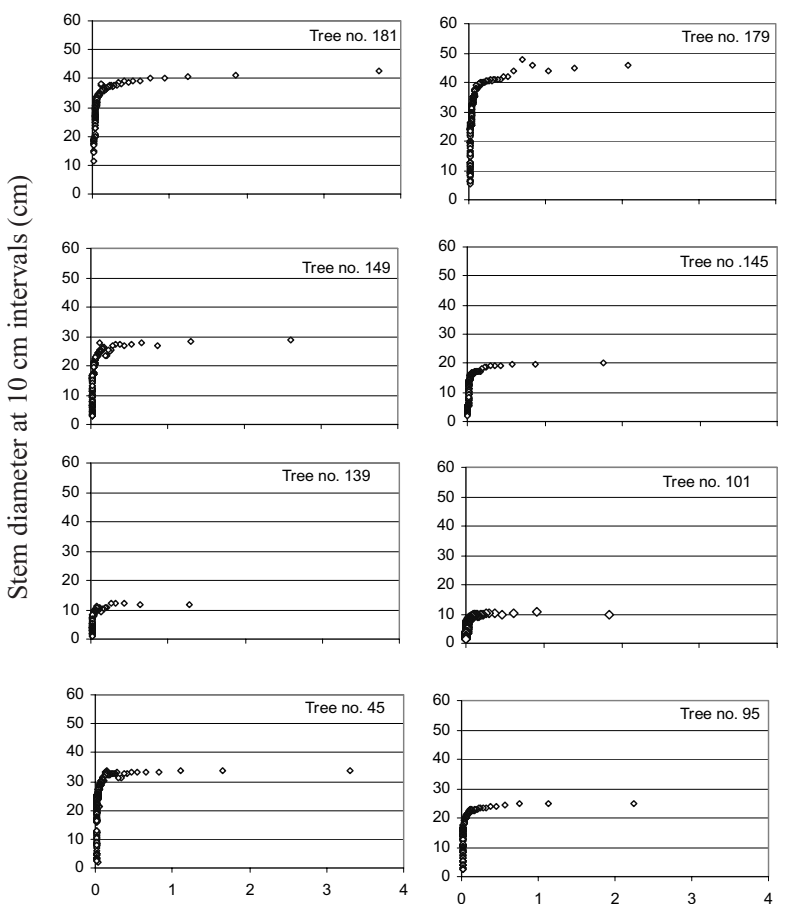

$\mathrm{dbh} /$ stem length from tree base to the point of diameter measurement

Figure 1: Scatter plots of stem diameter at $10 \mathrm{~cm}$ intervals versus diameter at breast height ( $\mathrm{dbh})$ for eight harvested trees, representing the diameter categories (1-4, 5-9, 10-14, 15-19, 20-24, 25-29, 30-34, 35-39 cm), from the Pinus stand in lower Hantana. height, height to the lowest live branch, stem diameter at the two ends, middle and immediately below the lowest live branch of the pine trees harvested were recorded at the time of logging. Using the above diameter data as a guide, 24 harvested pine trees representing eight size classes: 1-4, 5-9, 10-19, 20-24, 25-29, 30-34, 35-39, and 40-44 $\mathrm{cm}$ dbh (three individuals from each dbh class) were randomly selected for the biomass estimation. From each of the 24 trees selected, fresh samples of stem discs at the root collar, middle and top were collected, and dried at $70{ }^{\circ} \mathrm{C}$ to constant weight. The fresh weight of branches, needles and cones were recorded. Sub-samples of these were taken for the determination of fresh weight:dry weight ratios. For prediction of the tree form, one tree per each dbh category was randomly taken. From each of these trees, diameters at $10 \mathrm{~cm}$ intervals along the stem length were recorded.

The form of pine trees was determined by selecting one harvested tree and plotting its diameter data at $10 \mathrm{~cm}$ intervals on the stem, versus diameter at breast height $(\mathrm{dbh}$ in $\mathrm{cm}) /$ stem length above the root collar up to the point of diameter measurement for each of the eight trees selected from each dbh class. The above ground biomass was also calculated using the merchantable wood volume.

Above ground biomass density $(\mathrm{t} / \mathrm{ha})=$ volume $\mathrm{x}$ wood density $\mathrm{x}$ biomass expansion factor ${ }^{3}$

Wood density $=0.57$;

Biomass expansion factor $=1.3$

Volume of cylindrical part was calculated using $\pi \mathrm{r}^{2} \mathrm{~h}$ and volume of conical part was calculated using $1 / 3 \pi{ }^{2} h$ Where $r=$ radius of stem disc; $h=$ length of stem disc

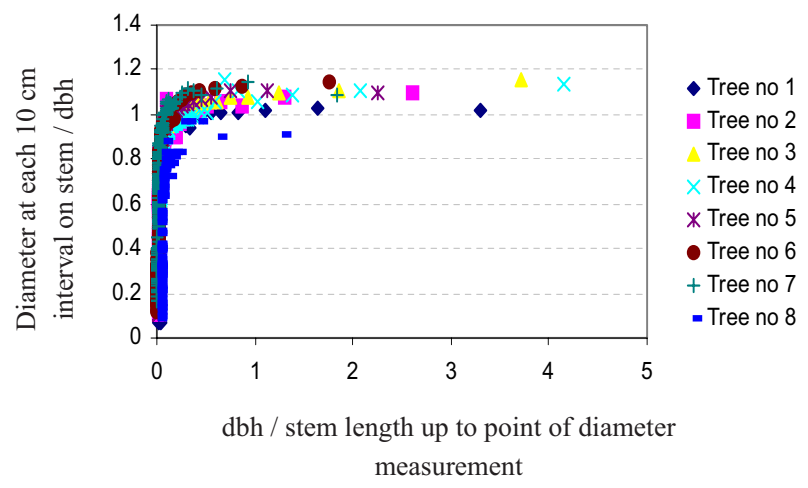

Figure 2: Scatter plots of diameter at each $10 \mathrm{~cm}$ interval on stem / diameter at breast height (dbh) versus dbh / stem length from tree base to the point of diameter measurement for eight harvested trees, representing the diameter categories (1-4, 5-9, 10-14, 15-19, 20-24, 25-29, 30-34, 35-39 cm), from the Pinus stand in lower Hantana. 


\section{RESULTS}

Graphs in Figure 1 show that the Pinus trunk is cylindrical at its lower part and conical at its upper part. Therefore, two different formulae were constructed to estimate the cylindrical and conical parts of the stem.

\section{Formulae for the cylindrical part of the stem}

To estimate the biomass of the cylindrical part of the stems, diameter at $10 \mathrm{~cm}$ intervals/dbh $(\mathrm{cm})$ versus $\mathrm{dbh}$ $(\mathrm{cm}) /$ stem length up to the point of diameter measurement (cm) were plotted for 8 trees using the Curve Expert Program (Curve Expert 1.3, A comprehensive curve fitting system for windos) (Figure 2). Then, the bestfitted regression equation was constructed, which took the following form.

$\mathrm{Y}=\mathrm{ae}^{(\mathrm{b} / \mathrm{x})}$

Where, $\mathrm{Y}=$ diameter $(\mathrm{d})$ at each $10 \mathrm{~cm}$ interval on stem/ $\mathrm{dbh}(\mathrm{D})$ and $\mathrm{X}=\mathrm{dbh}(\mathrm{D}) /$ corresponding stem length (L) up to the point at which diameter was measured

$\mathrm{a}=1.074 ; \mathrm{b}=-0.013 ; \mathrm{e}=\exp$

$\mathrm{d} / \mathrm{D}=1.074 \mathrm{e}^{-(0.013 \mathrm{~L} / \mathrm{D})}$

$\mathrm{R}^{2}=0.78 * *(\mathrm{p}<0.01)$

\section{Model validation}

Diameters of the 24 trees were also predicted using equation (1). Then, the predicted and observed diameters were plotted to check whether the model is valid. Values of the upper part of the tree (diameters $<15 \mathrm{~cm}$ ) deviated. These deviated values, which imply a conical shape, represent the tree tops.

Then, using the Curve Expert Program, a best-fit regression equation was developed for the graph (b) in
Figure 3 to calculate the weight per tree stem, as given below. It took the following form.

$\mathrm{Y}=\mathrm{a} \mathrm{X}^{\mathrm{b}}$

where, $\mathrm{Y}=$ diameter $(\mathrm{d})$ at each $10 \mathrm{~cm}$ interval on stem and $\mathrm{X}=$ weight $/ 1 \mathrm{~cm} \mathrm{disc}\left(\mathrm{w}_{\text {per cm }}\right)$

$\mathrm{a}=1.89 ; \quad \mathrm{b}=0.462 ; \mathrm{R}^{2}=0.97 * *$

$\mathrm{d}=1.89\left(\mathrm{w}_{\text {per cm }}\right)^{0.462}$

Integration of $\mathrm{w}_{\text {per } \mathrm{cm}}$ along the total stem length up to $15 \mathrm{~cm}$ stem diameter gives the weight per stem $\left(\mathrm{W}_{\text {stem }>15}\right)$

$\mathrm{W}_{\text {stem }>15}=\int \mathrm{W}_{\text {per cm }} \mathrm{dL}$

By solving and rearranging the three equations (1), (2) and (3), we get the following equation.

$\left.\begin{array}{rl}\mathrm{W}_{1}= & 10.5 \sum \mathrm{D} \mathrm{e}^{\log \exp (2.16 \mathrm{D})}- \\ & 10.5 \sum \mathrm{D} \exp \left(\log \mathrm{e}^{2.16 \mathrm{D}-0.028 \mathrm{~h} / \mathrm{D}}\right)\end{array}\right\}$

where, $\mathrm{W}_{1}=$ weight of tree stem up to $15 \mathrm{~cm}$ diameter on the trunk;

$\mathrm{D}=$ diameter at breast height $(\mathrm{dbh})$

$\mathrm{h}=$ length of the tree stem up to $15 \mathrm{~cm}$ stem diameter on the trunk.

Evaluating tree stem height up to $15 \mathrm{~cm}$ diameter on the trunk (h)

By substituting $\mathrm{d}=15 \mathrm{~cm}$ to equation (1), we get,

$15 / \mathrm{D}=1.074 \mathrm{e}^{-(0.013 \mathrm{~L} / \mathrm{D})}$

$\mathrm{L}=\mathrm{D} / 0.013 \ln (\mathrm{D} * 1.074) / 15$
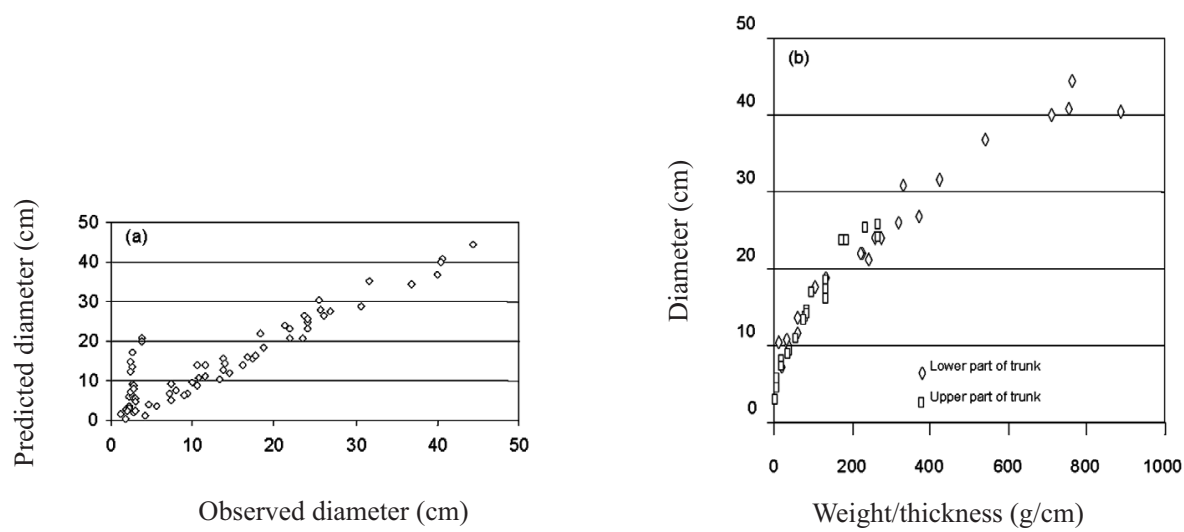

Figure 3: Scatter plots for model validation of predicted diameter versus observed diameter (a), and diameter versus weight/thickness of stem discs for upper and lower portions of tree trunks (b) of 24 trees harvested from the Pinus stand in lower Hantana 
As the length of the tree stem (L) up to $15 \mathrm{~cm}$ stem diameter on the trunk is $h, h$ in the equation (4) can be substituted by the equation (5).

\section{Formulae for conical part of the tree stem (part above $15 \mathrm{~cm}$ stem diameter)}

The plot of diameter versus weight/thickness for tree tops was constructed and an equation was developed to estimate the biomass of the conical part of the stem. It took the following form,

$\mathrm{Y}=\mathrm{a}+\mathrm{b} \mathrm{X}$

where, $\mathrm{Y}=$ weight $/$ thickness $(\mathrm{g} / \mathrm{cm})(\mathrm{W})$

and $\mathrm{X}=$ diameter $(\mathrm{cm})(\mathrm{d})$

$\mathrm{a}=-2.288 ; \mathrm{b}=1.937 ; \mathrm{R}^{2}=0.94 * *$

$\mathrm{W}=1.937 \mathrm{~d}-2.288$

As the shape of the Pinus tree-top is conical, we can use the following equation.

$\mathrm{r}=7.5 \mathrm{~L} / \mathrm{Lo} ; \mathrm{d}=2 \mathrm{r}$

$\mathrm{r}=$ radius of base of the conical tree-top

Lo $=$ observed tree height - predicted tree height

$\mathrm{d}=15 \mathrm{~L} / \mathrm{Lo}$

Integration of $\mathrm{w}_{\text {per } \mathrm{cm}}$ along the stem with diameter $<15 \mathrm{~cm}$ gives the weight per stem $\left(\mathrm{W}_{\mathrm{stem}<15}\right)$

$\mathrm{W}_{\text {stem }<15}=\int \mathrm{W}_{\text {per cm }} \mathrm{dL}$

$\mathrm{W}_{\mathrm{u}}=\sum \mathrm{W}_{\text {stem }<15}=12.24 \sum \mathrm{Lo}$

where, $\mathrm{W}_{\mathrm{u}}=$ weight of tree stem beyond $15 \mathrm{~cm}$ diameter on the trunk (tree-top).

Biomass of tree trunk was calculated using equations (4) and (8). Biomass of branches, needles and cones were determined using fresh weight to dry weight ratio.

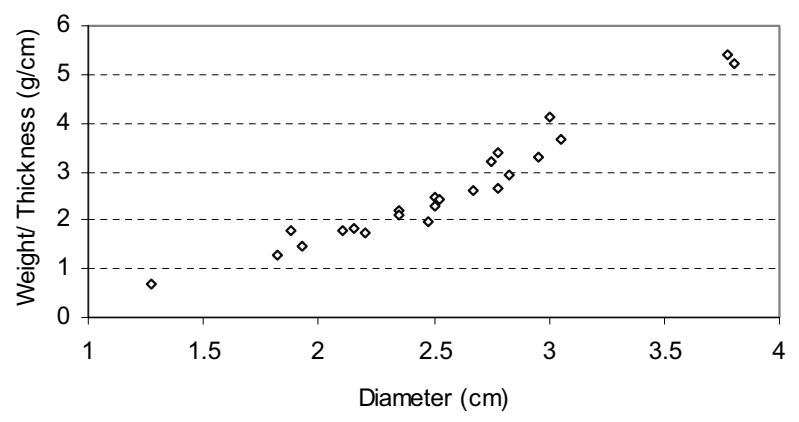

Figure 4: Scatter plot of weight/thickness of stem discs versus diameter of tree trunk above $15 \mathrm{~cm}$ stem diameter of 23 trees harvested from the Pinus stand in lower Hantana.
The characteristics of the pine stand and dry weight of each component of the pine trees are presented in Table 1. The total above ground biomass estimated for the 25 year-old $P$. caribaea stand in the lower Hantana was 194 t/ha. The stem represented $60 \%$ of the total dry weight.

Table 2 shows the quantities of above ground biomass produced by various stands of Pine plantations, as found in literature. Figure 5 depicts the relationship between the above ground biomass and age of stands of Pinus caribaea found in tropics, as of Table 2.

\section{DISCUSSION}

The higher value for the above ground biomass of P. caribaea stand obtained from the formulae developed from the site-specific empirical relationships (194 t/ha) than that obtained from allometric equations derived from standard volume functions (136 t/ha) suggest that, among others, site-specific climatic and topographic factors and the management history of the plantation may contribute to this difference. A study on biomass estimation of Virginia pine trees in the $\mathrm{USA}^{6}$ indicated that although the equations relating stem height of trees to measurements of size (stem diameter and height) could have more general applicability, the equations for the canopy components (live branches, canopy depth and needle mass) may be less reliable and vary considerably from tree to tree due to variability in canopy conditions, available growing space, land form, environmental conditions etc. They further report that the variables like crown length and stem diameter at the base of the crown apparently lag behind changes in foliage and live branch weight which respond more rapidly to immediate changes in the environment of the tree. Similar reasoning could be given for the differences we have observed when using allometric equations derived from standard volume functions and our own empirical determinations

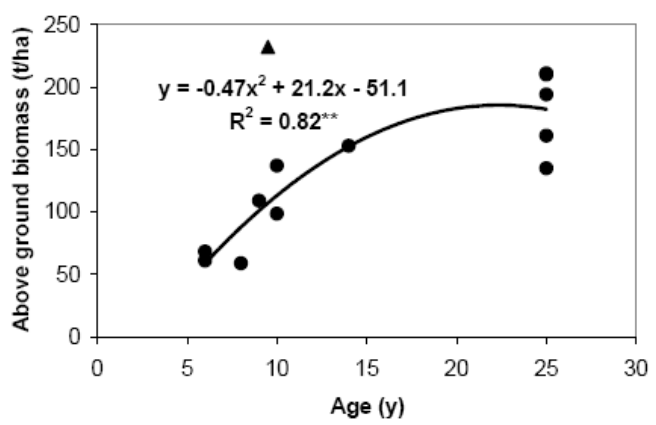

Figure 5: Relationship between above ground biomass and age of stands of Pinus caribaea found in tropics, as of Table 2. Filled triangle shows the data point of Russell et al. ${ }^{12}$, which is an outlier. 
of biomass. These derivations observed suggest that in rugged terrains in which pine plantations have been established in Sri Lanka, the site-specific variables, especially in the conical crown region may be less predictable from standard formulae. Therefore, further investigations of relationships between crown weights, growing space and age of pine plantations in different agro-ecological zones may be necessary to obtain more reliable prediction equations especially for the crown components of individual trees ${ }^{6}$.

Table 1: Tree characteristics (A), biomass partitioning and total dry weights (B) of two Pinus stands studied in lower Hantana in the present investigation, and the corresponding values obtained from $\mathrm{Khadka}^{7}$ in a similar study of the same plantation.

(A)

\begin{tabular}{lcc}
\hline Characteristics of the Pine stand & Present study & Khadka's study \\
\hline Plot area (ha) & 0.8 & - \\
Age (yr) & app. 25 & 20 \\
No. of trees (ha) & 695 & 899 \\
Mean dbh (cm) & 20.1 & 19.6 \\
Mean height (m) & 20.7 & 23.4 \\
Basal area /ha (m $/ \mathrm{ha})$ & 23.6 & 27.1 \\
\hline
\end{tabular}

(B)

\begin{tabular}{lcc}
\hline \multirow{2}{*}{$\begin{array}{l}\text { Component } \\
\text { parts }\end{array}$} & \multicolumn{2}{c}{ Biomass (t/ha) } \\
\cline { 2 - 3 } & Present study & Khadka's study \\
\hline Stem (with bark) & $117(60)$ & $37(16)$ \\
Branches & $47(24)$ & $9(4)$ \\
Needles (with twigs) & $25(13)$ & - \\
Cones & $5(3)$ & $231(100)$ \\
Total biomass & $194(100)$ & $37(16)$ \\
\hline
\end{tabular}

Values within parentheses are percentages of total biomass.

$\mathrm{Khadka}^{7}$ studied the above ground biomass of the P. caribaea plantations established in the foothills of the Hantana on land belonging to the University of Peradeniya which lies at an altitude between 1000 and $1500 \mathrm{msl}$. In that study, stem and bark represented 79.7\% of total biomass; branches and dead branches 16.1\%; needles and twigs $4.1 \%$. They are comparable with the values obtained in the present study (Table 1). The stand characteristics in his study were as follows: 899 trees/ha; $19.6 \mathrm{~cm}$ mean $\mathrm{dbh} ; 27.1 \mathrm{~m}^{2} /$ ha basal area; $23.4 \mathrm{~m}$ mean tree height. He reported an above ground biomass of $231 \mathrm{t} / \mathrm{ha}$, which was higher than that of the present study. Dharmaparakrama $^{8}$ reported above ground biomass estimates of a 23-27 year old $P$. caribaea plantations in Knuckles in the mid country wet zone as $211 \mathrm{t} /$ ha and mid and up country intermediate zone as $161 \mathrm{t} /$ ha and $135 \mathrm{t} / \mathrm{ha}$, respectively. In that study, density, dbh and height of the trees in the mid country wet zone were 673 trees/ha, $18 \mathrm{~cm}$ and $26 \mathrm{~m}$, respectively, mid country - intermediate zone 351 trees/ha, $25 \mathrm{~cm}$ and $27 \mathrm{~m}$, respectively and up country intermediate zone 463 trees/ha, $19 \mathrm{~cm}$ and $21 \mathrm{~m}$, respectively. He has further reported that tree height and dbh varied according to the climate and soil conditions prevailing at the sites. Rainfall (75\% annual rainfall expectancy) of wet zone-mid country site, and the intermediate zone-mid and up country sites were $>$ $1400,>2000$ and $>2400 \mathrm{~mm}$, respectively and mean sea levels of low country, mid country and up country were $300,300-1000$ and $100-2500 \mathrm{~m}$, respectively.

In our study site at lower Hantana, which lies at an altitude between 500 and $700 \mathrm{~m}$, the altitude, rainfall, and the variability of soil and wood density may have been responsible for the differences in above ground biomass recorded in the present study, compared to those of the Knuckles region.

Egunjobi ${ }^{11}$, and Egunjobi and Bada $^{12}$ reported above ground biomass ranging from 59 to $137 \mathrm{t} /$ ha for 6-10 year old $P$. caribaea stands in Ibadan, Nigeria (Table 2). These values are not comparable with the values of the present study as they are much younger stands. On the other hand, a P. caribaea stand of 9.5 years from eastern Amazon ${ }^{11}$ was reported to have an above ground biomass 
Table 2: Above ground biomass produced by various stands of Pine plantations, as found in literature.

\begin{tabular}{|c|c|c|c|}
\hline $\begin{array}{l}\text { Species and } \\
\text { stand age }(\mathrm{y})\end{array}$ & Location & $\begin{array}{l}\text { Biomass } \\
(\mathrm{t} / \mathrm{ha})\end{array}$ & Reference \\
\hline \multicolumn{4}{|l|}{ Pinus caribaea } \\
\hline 25 & Lower Hantana & 194 & Present study \\
\hline 25 & Lower Hantana & 231 & 8 \\
\hline $23-27$ & $\begin{array}{l}\text { Wet zone - Mid country } \\
\text { (Knuckles) }\end{array}$ & $211)$ & \\
\hline $23-27$ & $\begin{array}{l}\text { Intermediate zone, Mid country } \\
\text { (Knuckles) }\end{array}$ & 161 & 9 \\
\hline $23-27$ & $\begin{array}{l}\text { Intermediate zone, Up country } \\
\qquad \text { (Knuckles) }\end{array}$ & $135)$ & \\
\hline 14 & Agudos (Brazil) & 153 & 12 \\
\hline 10 & Northern Guinea savanna (Nigeria) & 98.7 & 13 \\
\hline 9.5 & Eastern Amazon & 232.2 & 14 \\
\hline 10 & Ibadan (Nigeria) & 137 & \\
\hline 9 & Ibadan (Nigeria) & 109 & 11 \\
\hline 8 & Ibadan (Nigeria) & 59 & \\
\hline 6 & Ibadan (Nigeria) & 61 & \\
\hline 6 & Ibadan (Nigeria) & 68.3 & 10 \\
\hline \multicolumn{4}{|l|}{ P. radiata } \\
\hline 7 & Australia & 50.7 & 10 \\
\hline \multicolumn{4}{|l|}{ P. ensiflora } \\
\hline 15 & Japan & 52.8 & 16 \\
\hline \multicolumn{4}{|l|}{ P. nigra } \\
\hline 18 & Scotland & $27.7\}$ & 17 \\
\hline $\begin{array}{l}\text { P. sylvestris } \\
18\end{array}$ & Scotland & 54.9 & \\
\hline
\end{tabular}

of $232.2 \mathrm{t} / \mathrm{ha}^{7}$, a value much higher than that of an older plantation. Different climatic and soil conditions may have influenced those differences.

The above ground biomass of $P$. caribaea in Sri Lanka ranged from 135-231 t/ha (Table 2). Other research on $P$. caribaea have focused on the basic density and fibre length in a 24-year $P$. caribaea at Erabedde in the montane $z o n e^{13}$ and tree volume and taper function for 7 year old $P$. caribaea in the wet zone ${ }^{14}$.

Comparison of the stand productivity of tropical pine with that of temperate ones indicates that the tropical pine is more productive (Table 2). The longer growing season in the tropics may have contributed to the high productivity. Another probable contributing factor is the high density of trees in the stands. The 24 year old Dalbergia sissoo Roxb. in India yields a total of $186 \mathrm{t} / \mathrm{ha}$ dry above ground biomass ${ }^{15}$, which is lower than that of pine trees. Similarly, the above ground biomass of a 30 year old Teak (Tectona grandis) plantation, another popular plantation species in Sri Lanka, was $141 \mathrm{t} / \mathrm{ha}^{15}$. Negi and Sharma ${ }^{17}$ report an above ground biomass of $121 \mathrm{t} /$ ha for a Eucalyptus hybrid; another study reports 112-300 t/ha for Eucalyptus grandis ${ }^{18}$ and 175 t/ha for Populus deltoides ${ }^{19}$, the second most popular exotic species widely planted in the Indian sub-continent. Another important species of the sub-continent is Sal (Shorea robusta). The above ground biomass of a 100 year old sal forest was reported to vary from 200$710 \mathrm{t} / \mathrm{ha}$, that of a Pinus roxburghii stand was $233.78 \mathrm{t} /$ $\mathrm{ha}^{20}$ and a Pinus tabulaeformis stand was $146.05 \mathrm{t} / \mathrm{ha}^{19,20}$. The relationship shown in Figure 5 can also be used to predict the above ground biomass of $P$. caribaea found in tropics, at different ages, up to 25 years. It is apparent that in $P$. caribaea stands up to the age of 25 years in the tropics, the highest above ground biomass is attained at the age of ca. 22 years (Figure 5). This may be a useful guide for the management of the pine plantations in the humid tropics which needs to be validated for plantations in different climatic and topographic conditions. 


\section{CONCLUSION}

The above ground biomass of 25 year old $P$. caribaea stands in lower Hantana was 194 t/ha. Thus, it seems that this exotic species is a good sink of sequestered carbon. The derived empirical formulae in this study are best recommended for pine tree stands in the Hantana plantation, and other plantations if the stand characteristics are comparable. The analysis of available data from the tropics suggest that the $P$. caribaea plantations gain maximum above ground biomass when it reaches ca. 22 years.

\section{Acknowledgement}

We acknowledge the receipt of a United States Department of Agriculture grant through the Department of Agriculture, Sri Lanka and its administration through the Postgraduate Institute of Science at University of Peradeniya. The facilities provided by the Department of Botany, University of Peradeniya and the field and laboratory work carried out by graduate field assistants and other field staff are much appreciated. The Forest Department and the State Timber Corporation of Sri Lanka are thanked for assisting in pine harvesting operations.

\section{References}

1. Food \& Agriculture Organization (2005). State of World's Forest 2005. Food \& Agriculture Organization, Rome, Italy.

2. Bandaratilleke H.M. (1988). Development of Pine plantations in Sri Lanka. In: Reforestation with Pinus in Sri Lanka (Eds. H.P.M. Gunasena, S. Gunatillake \& A.H. Perera). Proceedings of a symposium, organized by University of Peradeniya and British High Commission on behalf of ODA, July 1998.

3. http://www.fao.org/docrep/w4095e/w4095se06.htm.

4. Domros M. (1974). The Agroclimate of Ceylon, Franz Steiner Verlag GMBH, Wiesbaden, Germany.

5. Mapa R.B., Somasiri S. \& Nagarajah S. (1999). Soils of the Wet Zone of Sri Lanka; Morphology, Characterization and Classification. p.184 Soil Science Society of Sri Lanka. P.O. Box 10, Peradeniya.

6. Madgwick H.A.I. \& Kreh R.E. (1980). Biomass estimation of Virginia pine trees and stands. Forest Science 26(1): 107-111.
7. Khadka M. (2005). Above ground biomass of Pinus caribaea- a study from Hantana forest, Sri Lanka. M. Sc. Thesis. University of Natural Resources and Applied Life Science (Boku), Vienna, Austria.

8. Dharmaparakrama A.L.S. (2006). Carbon sequestration in major land use types in the Knuckles forest and surrounding region, Sri Lanka. Ph. D. Thesis, University of Natural Resources and Applied Life Sciences (Boku), Vienna, Austria.

9. Egunjobi J.K. (1975). Dry matter production by an immature stand of Pinus caribaea L. in Nigeria. Oikos 26(1): 80-85.

10. Egunjobi J.K. \& Bada S.O. (1979). Biomass and nutrient distribution in stands of Pinus caribaea L. in the dry forest zone of Nigeria. Biotropica 11(2): 130-135.

11. Poggiani F. (1985). Nutrient cycling in Eucalyptus and Pinus plantations ecosystems: silvicultural implications. Scientia Forestalis 31: 33-40.

12. Vivekanandan K. (1978). Retention of viability of Mahogany seed through cold storage. Sri Lanka Forester 13(3/4): 67-68.

13. Dayananda K.J.T. (1988). Tree volume and taper function for Caribbean pine plantations in Sri Lanka. Sri Lanka Forester 18(2): 115-120.

14. Sharma D.C., Taneja P.L. \& Bisht A.P.S. (1988). Biomass productivity and nutrient cycling in a Dalbergia sissoo plantation. Indian Forester 114(5): 261-268.

15. Jha K.K. (1995). Structure and functioning of an age series of Teak (Tectona grandis) plantations in Kumaun Himalayan Tarai. Ph. D. Thesis, Kumaun University, Nainital, India.

16. Negi J.D.S. \& Sharma M.C. (1985). Biomass and nutrient distribution in an age series of Eucalyptus hybrid plantation in Tamil Nadu. I. distribution of organic matter. Indian Forester 111(12): 1113-1124.

17. Tandon V.N., Pande M.C. \& Singh R. (1988). Biomass estimation and distribution of nutrients in five different aged Eucalyptus grandis plantations in Kerala State. Indian Forester 114(4): 184-199.

18. Kaul O.N. \& Sharma K.K. (1983). Biomass production system of Poplars and productivity in a Poplar plantation. Indian Forester 109(11): 822-828.

19. Rana B.S. (1985). Biomass and net primary productivity in different forest Himalayan. Ph. D. Thesis. Kumaun University, Nainital, India.

20. Negi J.D.S., Manhas R.K. \& Chauhan P.S. (2003). Carbon allocation in different components of some tree species of India: a new approach for carbon estimation. Current Science 85(11): 1528-1531. 